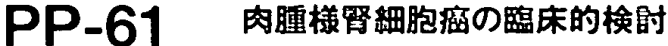

\begin{abstract}
長崎大学 医学部 泌尿器科" 長崎大学 大学院 医 学研究科 感染病態制御学 ${ }^{2}$ 長猗大学 医学部附属 病院病理部" 佐世保共済病院 泌尿器科"長崎市立病 院成人病センター 泌尿器科 ${ }^{5}$

大庭 康司郎",古賀 成彦", 錦戸 雅春", 宮田 康好"

野口 満" , 神田 聯" ${ }^{2}$, 林 徳真吉 ${ }^{32}$, 平自 定"

森光 浩(5), 山田 潤), 金武 洋"

【目的】肉腫棣婜細胞癌は比較的まれではあるが、予後不良 であることが知られている。今回われわれは肉腫㥞㹂細胞㿋 の臨床的検討を行った。方法】当科では 1982 年より 2000 年 までに 217 例の腎細胞㹸を経験した。この内肉腫様成分を含 む腎細胞癌 14 例 (6.9\%)を対象とした。成維】性別は男性 9 例、女性 5 例、年齢は 32 藏から 77 葴で、平均 59.5 藏。原発 巣の患㑡は右㑡 7 例、左㑡 7 例であった。13 例 (93\%)は初 診時、腹部腫撚、疼痛、全身倦急感など、何らかの症状を主 訴としていた。初診時、転移は 9 例 (64\%)にみられ、Robson 分類では、II 期 2 例、III 期 2 例、IV 期 10 例と high stage が多く腫㽷の最大径は $6 \mathrm{~cm}$ から $20 \mathrm{~cm}$ 、平均 $10 \mathrm{~cm}$ で あった。インターフェロン療法を 12 例に行ったが、癌特異的 5 年生存率は $10 \%$ 以下と予後不良であった。結論】肉腫様 腎細胞癌は浸潤、遠隔転移を来しやすく、非常に予後不良で あることが確認された。
\end{abstract}

腎細胞癌 臨床的検討

\section{PP-62 䁂紐胞瘾症例における血管新生因子の臨 床的検討}

国保日高総合病院1)有田市立病院 泌尿器科21 和歌山 労災病院 泌尿器科(3) 和歌山県立医科大学 泌尿器科(4 婥弘", 青枝 秀男", ,上門 康成 ${ }^{21}$, 藤永 卓治 ${ }^{3 \prime}$

平野 敦之", 新家 俊明4

【目的】腎綀胞㿋症例における血管新生因子と臨床的因子との 関係について検討した。方法と対象】1997年 11 月から 2000 年 12 月まで、4 施設で根治的腎摘除術が施行された腎細胞 㾰症例 51 例の摘出標本で、腫疼中心部之腫㾂より $5 \mathrm{~cm}$ 以上 離れた正常腎皮啠組織中の PyNPase・VEGF 活性を ELISA 法で測定した。症例は男性 35 例、女性 16 例で、平均年齢 $60.6 \pm 13.2$ 才であった。病理組織学的検討は「腎稹取扱い規約 (第 3 版) 」に染じた。結果了腫痛と正常腎組織内平均 PyN-

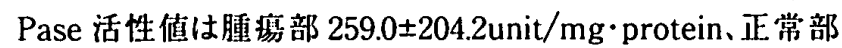
$76.0 \pm 83.9 u n i t / \mathrm{mg} \cdot$ protein で腫痛部は高い活性を示した( $<0.01$ )。同様に平均 VEGF 活性值でも腫㾂部 $10567 \pm 13949$

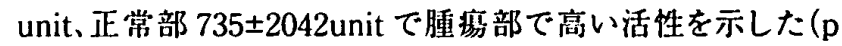
<0.01)。臨床的因子では PyNPase 活性と相関する因子はみ られなかったか、VEGF 活性では growth type・転移の有無・

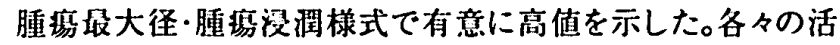
性値を 2 群に分䫓して検討すると、VEGF 活性高值群では再 発倾向がみられ、㹂細胞癌症例の再発予測因子の可能性を示 㖫した。さらに微小血管密度に関しても検討する予定である。 婜紐胞癌 血管新生因子

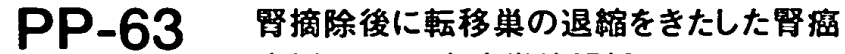
症例における免疫学的解析

\section{筑波大学 臨床医学系 泌尿器科" 理化学研究所 細胞開発銀行 ${ }^{21}$}

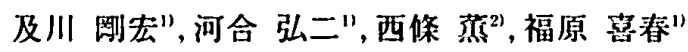

末富 崇弘", 塚本 定", 自居 徹", 大野忠夫"

赤座 英之"

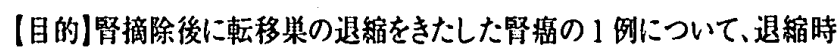
及び退縮後の末梢血中の各種免疫学的バラメー夕の検討を行った。症

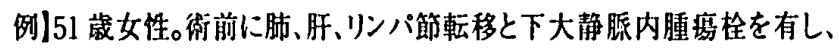

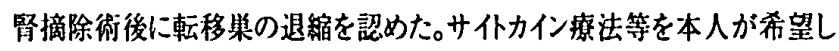
なかったため、6ヶ月間無治療で敞重に経過篗察を行った。(方法経過中 経時的に末梢血を採取し、単核球分画(PBMC)の表面マーカ一、血清中 の各種サイカイイン源度を検討するとともに、ナチュラルキラー(NK) 細胞を 誘導してその活性を比較㭘討した。NK 細胞は患者 PBMCと HFWT(ヒ

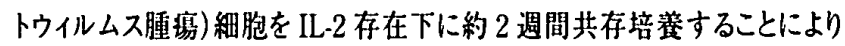
誘導した。成絰]1)PBMC 中の CD3 陽性紐胞の割合には有意な変化は なかったが、CD16 及びCD56 场性䋚胞の割合は経過中徐々に增加傾向 を示した。2）血清中のサ仆カイン泿度のうち、IL-6と TGF- $\beta 1$ が転移果の 退綰と共に変動したIFNyは退縮時に一過性に高值を示したがその後低 下した。なおIL-2の有意な変化は証められなかった。3)各時点で活性化 NK 綝胞の誘尊が可能であったが、伤害活性は経過中徐々に高くなる㑯 向を認めた。結論l本症例の転移菓の退縮及びその後の経過における、 絊胞性免疫反底の関与が示㖫された。(一部文科省振調费による) renal cell carcinoma idiopathic regression cellular immunity

\section{PP-64 腎細胞癌における interferon- $\alpha$ の有用性 について}

焼津市立総合病院 泌尿器科"浜松医科大学 泌尿器 科2) 東京大学 医学部 泌尿器科 ${ }^{3}$

鈴木 基文", 大塚 䉥史", 水野 卓爾",石川 晃"

河沿 香月", 滕田 公生", 北村 唯一"

【目的】腎練胞㾔に対する術後 interferon- $\alpha$ 療法の有用性に ついて統計学的検討を行った。対象と方法】1989 年 1 月から 2001 年 10 月までに当院で根治的腎摘除術を施行し、病理学 的に婜細胞㿂と診断された 90 例のうち、予後追跡可能であった 69 例を対象とした。病理組織学的診断は腎瘤取扱い规約第 3 版に準じた。生存率、非再発率は Kaplan-Meier 法を用いて算 出し、 logrank 検定による統計学的検討を行った。結果】69 例 の平均年齢は 61 葴 (25 82 藏)で、性別は男性 51 例、女性 18 例であった。Stage 別に見た 5 年生存率(症例数)はI期 $82.5 \%$ (42 例)、I期 87.5\% (11 例)、III 期 60.8\% (12 例)、IV 期 $0 \%$ (4 例)であった。術後 adjuvant 㙩法として interferon- $\alpha$ を投与した症例は 53 例であった。Stage 別に見た再発症例数 はI I 3 例、II 期 5 例、III 期 4 例、IV 期 0 例であった。 期で interferon- $\alpha$ の有用性を検討したところ、生存率に有意差 を認めなかったが、而期では interferon- $\propto$ を投与した群の方 が投与しなかった群よりも有意に予後が良かった $(\mathrm{p}=0.0002)$ 。 【とめ】Stage而期以上の婜細胞㿇症例には adjuvant 療法と して interferon- $\alpha$ を投与する意浽があると思われた。

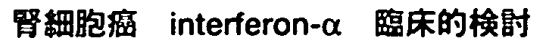

